\title{
Association of festival observance with psychological distress in a rural Japanese community
}

\author{
Tomohito Minamizono $^{1^{*}}$, Yoshihiro Kaneko ${ }^{1}$, Sachiko Minamizono ${ }^{2}$, Yutaka Motohashi ${ }^{1}$ \\ ${ }^{1}$ Department of Public Health, Akita University School of Medicine, Akita, Japan; \\ *Corresponding Author: tminamizono73@gmail.com \\ ${ }^{2}$ Department of Health Care Policy, Akita University Graduate School of Medicine, Akita, Japan
}

Received 11 June 2013; revised 12 July 2013; accepted 24 July 2013

Copyright (C) 2013 Tomohito Minamizono et al. This is an open access article distributed under the Creative Commons Attribution License, which permits unrestricted use, distribution, and reproduction in any medium, provided the original work is properly cited.

\begin{abstract}
Introduction: A growing body of evidence suggests that social capital improves mental health. However, the association between the observance of festivals and mental health has not yet been investigated in depth by public health researchers. The purpose of this study is to examine whether festival observance is associated with psychological distress. Methods: We conducted a cross-sectional survey of 17,525 residents aged 40 to 79 who lived in a rural town in northern Japan. We assessed each participant's psychological distress level, social capital and festival observance via a questionnaire. We performed multiple logistic regression analyses to examine the association of festival observance with psychological distress. Results: A total of 11,649 residents responded to this survey (a response rate of $66.5 \%$ ). The group who responded that their community did not hold festivals was negatively associated with psychological distress, even after adjusting for socio-demographic characteristics $(\mathrm{OR}=1.71,95 \%$ Cl 1.49 1.97). After adjusting for both socio-demographics and social capital, the association became weaker, but was still significant (OR $=1.27,95 \%$ $\mathrm{Cl} 1.10$ - 1.48). Conclusions: Festival observance was associated with psychological distress in a rural Japanese community. It seems that festival observance is a factor to be taken into consideration in mental health promotion in the community.
\end{abstract}

Keywords: Festival; Psychological Distress; Social Capital; Reciprocity; Trust; Attachment to

\section{Community}

\section{INTRODUCTION}

Several studies have focused on the effects of social capital on mental health. In recent years, systematic reviews using cross-sectional data have revealed that social capital is an important factor in the prevention of mental illness [1,2]. Additionally, a prospective study showed that a low level of social capital increases the prevalence of depression $[3,4]$. Social capital is thought to positively affect mental health by strengthening social ties and networks in the community [5]. Based on our previous studies in Japanese rural communities, we hypothesize that festivals have a positive effect on the mental health of residents by strengthening social ties within their community [6-8]. In festivals of Japan, one can always find booths selling souvenirs and food such as takoyaki, and games, such as Goldfish scooping and other forms of entertainments often organized in conjunction with festival.

There are also several studies that examine the sociological aspects of festivals. Festivals have significant economic, socio-cultural, and political impacts on the community [9]. By increasing revenue and providing employment, festivals have brought positive economic effects to the communities that celebrate them $[10,11]$. By encouraging citizens to participate in the development and execution of festival activities as a part of the shared life of the community, festivals have a positive impact on the local social and cultural climate [12]. However, the traffic congestion, vandalism, overcrowding, and increased crime that accompany the events may confer negative sociocultural influences in the community [10].

Two effects are to be considered when examining the 
effects of festivals on mental health: the effect of festival attendance, and the effect of people's acknowledgement of the festival. First, festival attendance may increase both physical and mental exertion at the time of the festival, leading to decreased psychological distress. Second, the cognitive aspect of festivals, i.e., how people integrate festivals in their daily lives, may mitigate psychological distress by reminding them of the excitement of previous events. In this study, we focused on the cognitive effects of festivals, how people integrate festival in their daily lives, because people's acknowledgement that a festival is taking place seems to be more associated with mental health than attending in the festival. However, the association between festivals and mental health has not yet been investigated from a public health perspective. Thus, the purpose of this study was to examine whether people's observance of festivals was associated with psychological distress in a rural Japanese community.

\section{Methods}

\subsection{Sample and Procedure}

We used a population sample drawn from a rural town in Akita Prefecture, located in northern Japan. We conducted a survey from May through June 2007 using community volunteers to distribute questionnaires to all households and then to collect them 2 weeks later. Our target population consisted of non-institutionalized town residents aged 40 to 79 . Of 31,869 total residents, 17,525 met these screening criteria. A total of 11,649 residents responded to this survey (a response rate of $66.5 \%$ ).

\subsection{Questionnaire}

The questionnaire sought data on demographic variables, education level, psychological distress, social capital and festival observance. Festival observance was assessed using the yes-or-no question, "Are there festivals where you live?" Social capital was assessed using the following questions: "Do you feel that people around here are willing to help their neighbors?" (intended to determine the level of reciprocity and trust), and "Do you feel you have an attachment to the community where you live?" (intended to determine the level of attachment to the community). Each of these questions was answered on a four-point scale: "Always", "Often", "Rarely", or "Never".

The level of severity of psychological distress was assessed using the K6 Scale [13]. The K6 scale, developed by Kessler et al., consists of six questions and is used to measure the extent of psychological distress using a five-point response option from 0 ("Never") to 4 ("Always") on a 0 - 24-point scale. The K6 scale was translated into Japanese and its internal consistency reliability and validity were reported to be acceptable for the Japanese-language version [14]. We defined the psychological distress group as those scoring 9 points or higher.

Educational background was classified into three levels: "completed compulsory education (9 years or less)"; "high school graduate (10 - 12 years)"; "junior college graduate, vocational school graduate, or other higher education (more than 13 years)".

\subsection{Statistical Analysis}

The association between social capital, festival observance, and socio-demographic characteristics was tested using Spearman's rank-order correlation analyses or Pearson's $\chi^{2}$ tests. We performed multiple logistic regression analyses to examine the associations of festival observance with psychological distress. First, we analyzed these associations without adjustment for other variables (Model 1). Then, we analyzed the associations after adjusting for socio-demographic characteristics (Model 2). Finally, we analyzed the associations after adjusting for social capital and socio-demographic characteristics (Model 3). We conducted the statistical analyses using SPSS version 11.5 software (Chicago, IL).

\subsection{Ethics}

This survey was approved by the Ethics Committee of the School of Medicine at Akita University.

\section{Results}

Table 1 displays the demographic characteristics of the participants. Of the 11,649 residents who returned questionnaires, $8729(74.9 \%)$ gave complete answers for all variables included in the logistic regression analysis. The mean age was 59.4 years $(\mathrm{SD}=10.0)$, and $11.9 \%$ of respondents were classified as having high psychological distress. Most of the respondents felt a sense of reciprocity and trust $(30.2 \%$ selecting "Always", and $52.3 \%$ selecting "Often") and had a sense of attachment to their community (33.8\% selecting "Always", and $51.8 \%$ selecting “Often").

There was a positive correlation between a sense of reciprocity and trust and a sense of attachment to the community (Spearman's $\rho=0.49$ ). There was a positive correlation between sense of reciprocity and trust and festival observance (Spearman's $\rho=0.20$ ). There was a positive correlation between sense of attachment to the community and festival observance (Spearman's $\rho=$ $0.17)$.

Table 2 shows the distributions of psychological distress by demographic characteristics and social capital. Women, younger age, lower education levels, respondents who reported less social capital, and respondents who reported that their communities do not hold festivals 
Table 1. Characteristics of participants $(n=8729)$.

\begin{tabular}{|c|c|c|}
\hline Variables & $\mathbf{n}$ & $\%$ \\
\hline \multicolumn{3}{|l|}{ Gender } \\
\hline Male & 4020 & 46.1 \\
\hline Female & 4709 & 53.9 \\
\hline \multicolumn{3}{|l|}{ Age } \\
\hline $40-49$ & 1707 & 19.6 \\
\hline $50-59$ & 2915 & 33.4 \\
\hline $60-69$ & 2300 & 26.3 \\
\hline $70-79$ & 1807 & 20.7 \\
\hline \multicolumn{3}{|c|}{ Educational background (in years) } \\
\hline 9 or less & 3210 & 36.8 \\
\hline $10-12$ & 3825 & 43.8 \\
\hline 13 or more & 1694 & 19.4 \\
\hline \multicolumn{3}{|c|}{ Are there festivals where you live? } \\
\hline Yes & 6698 & 76.7 \\
\hline No & 2031 & 23.3 \\
\hline \multicolumn{3}{|c|}{ Reciprocity and trust } \\
\hline Always & 2638 & 30.2 \\
\hline Often & 4568 & 52.3 \\
\hline Rarely & 1260 & 14.4 \\
\hline Never & 263 & 3.0 \\
\hline \multicolumn{3}{|c|}{ Attachment to community } \\
\hline Always & 2949 & 33.8 \\
\hline Often & 4521 & 51.8 \\
\hline Rarely & 965 & 11.1 \\
\hline Never & 294 & 3.4 \\
\hline \multicolumn{3}{|c|}{ Psychological distress (K6) ${ }^{*}$} \\
\hline Distressed & 1036 & 11.9 \\
\hline Not distressed & 7693 & 88.1 \\
\hline
\end{tabular}

had significantly higher proportions of participants suffering from psychological distress.

Table 3 shows the results of multiple logistic regression analyses. The group that responded that their communities did not hold festivals was negatively associated with psychological distress even after adjusting for the socio-demographic characteristics of participants $(\mathrm{OR}=$ $1.71,95 \%$ CI 1.49 - 1.97). After adjusting for both socio-demographic characteristics and social capital, the association became weaker, but was still significant (OR
$=1.27,95 \%$ CI $1.10-1.48)$. Among the demographic variables, gender, age group and education background were significantly associated with psychological distress in Model 3.

\section{Discussion}

Results indicated that festival observance was independently associated with psychological distress after adjusting for two social capital variables (Model 3).

There are two possible explanations for the association of observance of festivals with psychological distress. The first explanation is that the entertainment aspect of festivals has an ameliorating effect on psychological distress. Festivals provide entertainment and cultural interaction in the community [15]. People reported entertainment and fun as motivation to attend festivals [16-22]. Amusement and entertainment is thought to decrease levels of psychological distress.

The second explanation is that festivals strengthen social capital, which in turn brings about an ameliorating effect on psychological distress. Several reports explain the relationship between festival attendance and social capital. Festival attendance may develop social capital by providing the community with specific opportunities for accessing and developing community resources, improving social cohesiveness, and providing a focus for celebration [9]. Arcodia and Whitford reported that organizing a festival raises awareness of community resources, produces social links among previously unrelated individuals, and encourages greater interaction among existing community organizations [9].

Falassi reported that festival attendance can develop social capital by providing social cohesiveness [23]. Attanasi also reported that cultural events, such as festivals, could facilitate social capital by involving local communities, which generates civic pride and a sense of belonging [24]. However, the association between festivals and mental health has not yet been investigated in depth by public health researchers.

Several reports confirmed the relationship between social capital and psychological distress. Social capital is thought to decrease psychological distress by strengthening social ties and networks in the community [5]. Living in a community with a high level of social trust may have a direct inverse relationship with psychological distress. Interactions with trusted neighbors may produce positive psychological states, such as a sense of being accepted within the community [3,5]. Alternatively, a higher level of social trust within a community may foster healthrelated social norms (i.e., more physical activity, nonsmoking), which may have a protective effect against psychological distress [3,5].

Besides festivals, prior studies suggest that involvement in other social activities improve mental health [25- 
Table 2. Distributions of those with psychological distress by demographic characteristics among study participants.

\begin{tabular}{|c|c|c|c|}
\hline Variable & \multicolumn{2}{|c|}{ No. of case $(\%)$} & $\begin{array}{c}\boldsymbol{P} \\
0.002\end{array}$ \\
\hline Male & 431 & $(10.7)$ & \\
\hline Female & 605 & $(12.8)$ & \\
\hline Age & & & 0.002 \\
\hline $40-49$ & 244 & $(14.3)$ & \\
\hline $50-59$ & 352 & $(12.1)$ & \\
\hline $60-69$ & 228 & $(9.9)$ & \\
\hline $70-79$ & 212 & $(11.7)$ & \\
\hline Educational background (in years) & & & 0.002 \\
\hline 9 or less & 422 & $(13.1)$ & \\
\hline $10-12$ & 439 & $(11.5)$ & \\
\hline 13 or more & 175 & $(10.3)$ & \\
\hline Are there festivals where you live? & & & $<0.001$ \\
\hline Yes & 694 & $(10.4)$ & \\
\hline No & 342 & $(16.8)$ & \\
\hline Reciprocity and trust & & & $<0.001$ \\
\hline Always & 206 & $(7.8)$ & \\
\hline Often & 502 & $(11.0)$ & \\
\hline Rarely & 226 & $(17.9)$ & \\
\hline Never & 102 & $(38.8)$ & \\
\hline Attachment to community & & & $<0.001$ \\
\hline Always & 202 & $(6.8)$ & \\
\hline Often & 499 & (11.0) & \\
\hline Rarely & 222 & $(23.0)$ & \\
\hline Never & 113 & $(38.4)$ & \\
\hline
\end{tabular}

\footnotetext{
*Psychological distress was defined as scoring 9 or more on the K6 scale; $P$ values were calculated by Spearman's rank-order correlations and Pearson $\chi^{2}$ tests ${ }^{* *}$.
}

27]. For example, religious membership [28] and volunteer work [29-32] increase individual social resources, as measured by meeting attendance and informal social interaction, and lower the incidence of depressive symptoms.

The present analyses have at least three limitations. First, festival observance, a sense of reciprocity and trust, and a sense of attachment to the community were assessed by only one question each. Additional research is required to validate the accuracy of these measures, but here we have confirmed their relevance. Second, our study was conducted with a cross-sectional design in only one small town. Our results may be influenced by the characteristics of this particular town. Further studies are required to confirm the causality between festival observance and psychological distress, ideally by using a cohort design in a large population. Finally, this was a self-administered survey. The potential for social desirability bias is always a concern; however, we consider it to be low in this study, because of the nature of the questions asked. The potential for social desirability bias was minimized by assuring participants that both the collection and analysis of the questionnaires were performed by a disinterested third party. 
Table 3. Associations between psychological distress and festival observance.

\begin{tabular}{|c|c|c|c|c|c|c|}
\hline \multirow[t]{2}{*}{ Variables } & \multicolumn{2}{|c|}{ Model 1} & \multicolumn{2}{|c|}{ Model 2} & \multicolumn{2}{|c|}{ Model 3} \\
\hline & OR & $(95 \% \mathrm{CI})$ & OR & $(95 \%$ CI) & OR & $(95 \% \mathrm{CI})$ \\
\hline \multicolumn{7}{|l|}{ Gender } \\
\hline Male & & & \multicolumn{2}{|c|}{ Reference } & \multicolumn{2}{|c|}{ Reference } \\
\hline Female & & & 1.21 & $(1.06-1.38)$ & 1.16 & $(1.02-1.33)$ \\
\hline \multicolumn{7}{|l|}{ Age } \\
\hline $40-49$ & & & 1.58 & $(1.26-1.97)$ & 1.18 & $(0.94-1.49)$ \\
\hline $50-59$ & & & 1.19 & $(0.98-1.44)$ & 1.00 & $(0.81-1.22)$ \\
\hline $60-69$ & & & 0.89 & $(0.73-1.09)$ & 0.81 & $(0.66-0.99)$ \\
\hline $70-79$ & & & \multicolumn{2}{|c|}{ Reference } & \multicolumn{2}{|c|}{ Reference } \\
\hline \multicolumn{7}{|c|}{ Educational background (in years) } \\
\hline 9 or less & & & 1.53 & $(1.25-1.88)$ & 1.61 & $(1.31-1.99)$ \\
\hline $10-12$ & & & 1.18 & $(0.97-1.42)$ & 1.22 & $(1.01-1.48)$ \\
\hline 13 or more & & & \multicolumn{2}{|c|}{ Reference } & \multicolumn{2}{|c|}{ Reference } \\
\hline \multicolumn{7}{|c|}{ Are there festivals where you live? } \\
\hline Yes & \multicolumn{2}{|c|}{ Reference } & \multicolumn{2}{|c|}{ Reference } & \multicolumn{2}{|c|}{ Reference } \\
\hline No & 1.75 & $(1.52-2.02)$ & 1.71 & $(1.49-1.97)$ & 1.27 & $(1.10-1.48)$ \\
\hline \multicolumn{7}{|c|}{ Reciprocity and trust } \\
\hline Always & & & & & \multicolumn{2}{|c|}{ Reference } \\
\hline Often & & & & & 1.16 & $(0.97-1.40)$ \\
\hline Rarely & & & & & 1.46 & $(1.16-1.85)$ \\
\hline Never & & & & & 2.68 & $(1.89-3.81)$ \\
\hline \multicolumn{7}{|c|}{ Attachment to community } \\
\hline Always & & & & & \multicolumn{2}{|c|}{ Reference } \\
\hline Often & & & & & 1.50 & $(1.24-1.80)$ \\
\hline Rarely & & & & & 3.11 & $(2.45-3.94)$ \\
\hline Never & & & & & 4.67 & $(3.34-6.52)$ \\
\hline
\end{tabular}

${ }^{*}$ The associations between psychological distress and festival observance were analyzed separately using 4 logistic regression models. Model 1: Without adjustment. Model 2: Adjusted for socio-demographic characteristics of participants (sex, age group, educational backgrounds). Model 3: Adjusted for sociodemographic characteristics of participants and social capital. OR - odds ratios, CI-confidence interval.

\section{Conclusion}

Festival observance was negatively associated with psychological distress in a rural Japanese community. It seems that festival observance in the community is a factor to be taken into consideration in mental health promotion in the community.

\section{REFERENCES}

[1] De Silva, M.J., McKenzie, K., Harpham, T. and Huttly, S.R.A. (2005) Social capital and mental illness: A systematic review. Journal of Epidemiology and Community

\section{Health, 59, 619-627. doi:10.1136/jech.2004.029678}

[2] De Silva, M.J. (2006) Systematic review of the methods used in studies of social capital and mental health. In: McKenzie, K. and Harpham, T., Eds., Social Capital and Mental Health, Jessica Kingsley, London, 39-67.

[3] Fujiwara, T. and Kawachi, I. (2008) A prospective study of individual-level social capital and major depression in the United States. Journal of Epidemiology and Community Health, 62, 627-633. doi:10.1136/jech.2007.064261

[4] Kim, S.-S., Chung, Y., Perry, M.J., et al. (2012) Association between interpersonal trust, reciprocity, and depression in South Korea: A prospective analysis. PloS One, 7, e30602. doi:10.1371/journal.pone. 0030602 
[5] Kawachi, I. and Berkman, L.F. (2001) Social ties and mental health. Journal of Urban Health: Bulletin of the New York Academy of Medicine, 78, 458-467. doi:10.1093/jurban/78.3.458

[6] Motohashi, Y., Kaneko, Y., Sasaki, H. and Yamaji, M. (2007) A decrease in suicide rates in Japanese rural towns after community-based intervention by the health promotion approach. Suicide \& Life-Threatening Behavior, 37, 593-599. doi:10.1521/suli.2007.37.5.593

[7] Kaneko, Y. and Motohashi, Y. (2007) Male gender and low education with poor mental health literacy: A population-based study. Journal of Epidemiology, 17, 114-119. doi:10.2188/jea.17.114

[8] Kaneko, Y., Motohashi, Y., Sasaki, H. and Yamaji, M. (2007) Prevalence of depressive symptoms and related risk factors for depressive symptoms among elderly persons living in a rural Japanese community: A cross-sectional study. Community Mental Health Journal, 43, 583590. doi:10.1007/s10597-007-9096-5

[9] Arcodia, C. and Whitford, M. (2006) Festival attendance and the development of social capital. Journal of Convention \& Event Tourism, 8, 1-18. doi:10.1300/J452v08n02_01

[10] Dwyer, L., Mellor, R., Mistilis, N., and Mules, T. (2000) Forecasting the economic impacts of events and conventions. Event Management, 6, 191-204.

[11] Brent Ritchie, J.R. (1984) Assessing the impact of hallmark events: Conceptual and research issues. Journal of Travel Research, 23, 2-11. doi: $10.1177 / 004728758402300101$

[12] Schuster, J.M. (1995) Two urban festivals: La Merce and First Night. Planning Practice and Research, 10, 173-188. doi:10.1080/02697459550036694

[13] Kessler, R.C., Andrews, G., Colpe, L.J., et al. (2002) Short screening scales to monitor population prevalences and trends in non-specific psychological distress. Psychological Medicine, 32, 959-76. doi:10.1017/S0033291702006074

[14] Furukawa, T.A., Kawakami, N., Saitoh, M., et al. (2008) The performance of the Japanese version of the K6 and K10 in the World Mental Health Survey Japan. International Journal of Methods in Psychiatric Research, 17, 152-158. doi: $10.1002 / \mathrm{mpr} .257$

[15] Liang, Y., Illum, S.F. and Cole, S.T. (2008) Benefits Received and Behavoral intentions of festival visitors in relation to distance travelled and their oringins. International Journal of Event Management Research, 4, 12-23.

[16] Uysal, M., Gahan, L. and Martin, B. (1993) An examination of event motivations: A case study. Festival Management and Event Tourism, 1, 5-10.

[17] Mohr, K., Backman, K.F., Gahan, L.W. and Backman, S.J. (1993) An investigation of festival motivations and event satisfaction by visitor type. Festival Management and Event Tourism, 1, 89-97. doi: $10.3727 / 106527093792337619$

[18] Scott, D. (1995) A comparison of visitors' motivations to attend three urban festivals. Festival Management and Event Tourism, 3, 121-128.
[19] Formica, S. and Uysal, M. (1996) A market segmentation of festival visitors: Umbria Jazz festival in Italy. Festival Management and Event Tourism, 3, 175-182. doi: $10.3727 / 106527095792232523$

[20] Schneider, I.E. and Backman, S.J. (1996) Cross-cultural equivalence of festival motivations: A study in Jordan. Festival Management and Event Tourism, 4, 139-144. doi: $10.3727 / 106527096792195380$

[21] Formica, S. and Uysal, M. (1998) Market segmentation of an international cultural-historical event in Italy. Journal of Travel Research, 36, 16-24. doi:10.1177/004728759803600402

[22] Lee, C.-K., Lee, Y.-K. and Wicks, B.E. (2004) Segmentation of festival motivation by nationality and satisfaction. Tourism Management, 25, 61-70. doi:10.1016/S0261-5177(03)00060-8

[23] Falassi, A. (1987) Festival: Definition and morphology. In: Falassi, A., Ed., Time out of Time, University of New Mexico Press, Albuquerque.

[24] Attanasi, G., Casoria, F., Centorrino, S. and Urso, G. (2012) Cultural investment, local development and instantaneous social capital: A case study of a gathering festival in the South of Italy (No. 12-291). Toulouse School of Economics.

http://www.tse-fr.eu/images/doc/by/attanasi/wp tse 291. pdf

[25] Chiao, C., Weng, L.-J. and Botticello, A.L. (2011) Social participation reduces depressive symptoms among older adults: An 18-year longitudinal analysis in Taiwan. BMC Public Health, 11, 292. doi:10.1186/1471-2458-11-292

[26] Gautam, R., Saito, T. and Kai, I. (2007) Leisure and religious activity participation and mental health: Gender analysis of older adults in Nepal. BMC Public Health, 7, 299. doi:10.1186/1471-2458-7-299

[27] Hamano, T., Fujisawa, Y., Ishida, Y., et al. (2010) Social capital and mental health in Japan: a multilevel analysis. PloS One, 5, e13214. doi:10.1371/journal.pone.0013214

[28] Ellison, C.G. and George, L.K. (1994) Religious involvement, social ties, and social support in a southeastern community. Journal for the Scientific Study of Religion, 33, 46-61. doi:10.2307/1386636

[29] Musick, M.A. and Wilson, J. (2003) Volunteering and depression: The role of psychological and social resources in different age groups. Social Science \& Medicine, 56, 259-269. doi:10.1016/S0277-9536(02)00025-4

[30] Li, Y. and Ferraro, K.F. (2005) Volunteering and depression in later life: Social benefit or selection processes? Journal of Health and Social Behavior, 46, 68-84. doi: $10.1177 / 002214650504600106$

[31] Thoits, P.A. and Hewitt, L.N. (2001) Volunteer work and well-being. Journal of Health and Social Behavior, 42, 115-131. doi:10.2307/3090173

[32] Sugihara, Y., Sugisawa, H., Shibata, H. and Harada, K. (2008) Productive roles, gender, and depressive symptoms: Evidence from a national longitudinal study of late-middle-aged Japanese. Journals of Gerontology Series B: Psychological Sciences and Social Sciences, 63, 227-234. doi:10.1093/geronb/63.4.P227 